\title{
Techno-economic evaluation of an ultrasound-assisted Enzymatic Reactive Distillation process
}

DOI:

10.1016/j.compchemeng.2017.01.042

\section{Document Version}

Accepted author manuscript

Link to publication record in Manchester Research Explorer

\section{Citation for published version (APA):}

Wierschem, M., Skiborowski, M., Górak, A., Schmuhl, R., \& Kiss, A. A. (2017). Techno-economic evaluation of an ultrasound-assisted Enzymatic Reactive Distillation process. Computers and Chemical Engineering, 105, 123-131. https://doi.org/10.1016/j.compchemeng.2017.01.042

\section{Published in:}

Computers and Chemical Engineering

\section{Citing this paper}

Please note that where the full-text provided on Manchester Research Explorer is the Author Accepted Manuscript or Proof version this may differ from the final Published version. If citing, it is advised that you check and use the publisher's definitive version.

\section{General rights}

Copyright and moral rights for the publications made accessible in the Research Explorer are retained by the authors and/or other copyright owners and it is a condition of accessing publications that users recognise and abide by the legal requirements associated with these rights.

\section{Takedown policy}

If you believe that this document breaches copyright please refer to the University of Manchester's Takedown Procedures [http://man.ac.uk/04Y6Bo] or contact uml.scholarlycommunications@manchester.ac.uk providing relevant details, so we can investigate your claim.

\section{OPEN ACCESS}




\title{
Techno-Economic Evaluation of an Ultrasound-Assisted Enzymatic Reactive Distillation Process
}

\author{
Matthias Wierschem, ${ }^{1, *}$ Mirko Skiborowski, ${ }^{1}$ Andrzej Górak, ${ }^{1,2}$ \\ Riaan Schmuhl, ${ }^{3}$ Anton A. Kiss ${ }^{4,5}$ \\ ${ }^{1}$ Laboratory of Fluid Separations, TU Dortmund University, Emil-Figge-Str. 70, 44227 \\ Dortmund, Germany \\ ${ }^{2}$ Department of Process and Environmental Engineering, Łódź University of Technology, \\ Stefana Żeromskiego 116, 90-924 Łódź, Poland \\ ${ }^{3}$ AkzoNobel, Industrial Chemicals, Competence Team Technology, Christian Neefestraat 2, \\ 1077 WW Amsterdam, The Netherlands \\ ${ }^{4}$ AkzoNobel Research, Development \& Innovation, Process Technology SRG, Zutphenseweg \\ 10, 7418 AJ Deventer, The Netherlands \\ ${ }^{5}$ Sustainable Process Technology Group, Faculty of Science and Technology, University of \\ Twente, PO Box 217, 7500 AE Enschede, The Netherlands \\ *Corresponding author: mirko.skiborowski@bci.tu-dortmund.de; +49(0)231-755/2670
}

\section{Abstract}

Enzymatic Reactive Distillation (ERD) is a bioreactive process, in which enzymes are immobilized on column internal surface, and helps to overcome chemical reaction and phase equilibrium limitations. The activation of enzymes by ultrasound (US) leads to ultrasoundassisted ERD (US-ERD) which might display more eco-efficiency than standard processing of valuable chemicals. Reaction rate improvements of more than $50 \%$ could be achieved by the assistance of US.

An US-ERD process for the synthesis of butyl butyrate (10 kilotons per year, 99 wt\% purity) was designed. A techno-economic evaluation via process optimization was carried out to minimize the annual costs, by using an evolutionary algorithm. The techno-economic evaluation shows that the US-ERD process and the ERD share nearly equal costs. Installation costs of the US equipment are high but they are compensated by a $12 \%$ lower reactive section height and a 7\% lower total height of the US-ERD column in comparison to ERD.

Keywords: Biocatalysis, Optimization, Process intensification, Sonochemistry 


\section{1. Introduction}

2 Process intensification (PI) in distillation aims at further increasing the sustainability, eco-

3 efficiency, production efficiency and yield of industrial processes (Lutze and Górak, 2013; Lutze et al., 2012; Schmidt-Traub and Górak, 2006; Shah et al., 2012). It comprises novel equipment, processing technologies, new catalysts and reaction routes and process development methods that offer significant improvements in (bio-) chemical processing among conventional processes (Lutze and Sudhoff, 2016; Schmidt-Traub and Górak, 2006). To combine chemical reaction and thermodynamic separation inside a single unit is one of the most known examples of PI (Górak and Stankiewicz, 2011; Schmidt-Traub and Górak, 2006). Conventional reaction-separation sequences can be outperformed by the integrated reactive separation processes which potentially lead to large savings of capital, energy, and materials by elimination of equipment for product recovery and recycling of unconverted reactants (Górak and Hoffmann, 2001; Górak and Stankiewicz, 2011; Schneider et al., 2001). Within green PI the integration of separation and biochemical reaction under mild conditions is one of three major components (Liu et al., 2010). One example of green PI is the combination of distillation technology with enzymatically catalyzed reactions which was successfully demonstrated, recently (Heils et al., 2015; Heils et al., 2014; Wierschem et al., 2016a). The first experimental investigation of an Enzymatic Reactive Distillation (ERD) process was reported by Paiva et al. (2003) for the synthesis of butyl butyrate $(\mathrm{BuBu})$ by the transesterification of ethyl butyrate $(\mathrm{EtBu})$ with butanol $(\mathrm{BuOH})$, using lipase as catalyst. On top of that Heils et al. investigated the usage of enzyme immobilized in a hydrophobic silica gel, which was applied as coating on structured packing (Heils et al., 2014; Heils et al., 2012). Furthermore the feasibility of the ERD was demonstrated with help of an ERD model-based analysis and with experiments in a batch ERD set-up (Heils et al., 2014; Heils et al., 2012). A continuous ERD process for the transesterification of EtBu was investigated by Wierschem et al. (2016b). Several experiments in a pilot-scale ERD column were conducted to show process feasibility and the outcome of this work is a validated ERD model that is able to precisely describe the ERD process (Wierschem et al., 2016b) and used within this work. $\mathrm{BuBu}$ is a volatile ester with a pleasant aroma, used in the flavor industry to create sweet fruity flavors similar to that of pineapple. Other esters used in the cosmetic industry can also be produced using enzyme-catalyzed synthesis routes (Khan and Rathod, 2015). These enzymatic reactions are often limited in conversion and are rather slow but can be intensified by using ultrasound (US) which leads to increased reaction rates and by applying distillation, which increases the conversion by in-situ product removal (Alves et al., 2014; Gharat and 
1 Rathod, 2013; Lye and Woodley, 1999; Thompson and Doraiswamy, 1999; Wierschem et al., 2 2017). The beneficial effects of US on the enzymatic reaction of the transesterification of 3 EtBu rate have recently been reported (Wierschem et al., 2017) indicating a 50\% increase in 4 the reaction rate compared to the unsonicated system at conditions of $338 \mathrm{~K}$ and an EtBu to $\mathrm{BuOH}$ molar ratio of $5 \mathrm{~mol} / \mathrm{mol}$. This work was the basis to validate the ERD model due to the investigation and determination of enzyme kinetics, which were subsequently implemented into the ERD model (Wierschem et al., 2016b). The synergies between US irradiation and ERD are now brought together in an integrated setup. Hence, this work is the first to propose an ultrasound-assisted Enzymatic Reactive Distillation (US-ERD) process. A techno-economic evaluation and optimization of the USERD process is performed, which is then compared against the optimized ERD process in which enzyme coated packing is solely used (no US). The comprehensive mathematical model of ERD which was previously developed to describe the mass transfer, packing properties and the catalyst kinetics (Wierschem et al., 2016b) is used here for the US-ERD process design and optimization. Figure 1 illustrates the proposed configuration for the USERD process. The capacity considered in our case study is 10 kiloton per year (ktpy) product stream of $\mathrm{BuBu}$ (99 wt\% purity), obtained by transesterification of $\mathrm{EtBu}$ with $\mathrm{BuOH}$ and yielding to ethanol (EtOH) as co-product (Eq. (1)).

$$
\mathrm{EtBu}+\mathrm{BuOH} \rightleftharpoons \mathrm{BuBu}+\mathrm{EtOH}
$$

The enzymatic catalyst, lipase B from the yeast Candida antarctica (CalB) (EC 3.1.1.3), is known as an efficient and robust enzyme catalyzing several organic reactions, including transesterification. Within ERD, the enzymes are immobilized in a thin film, coated on the surface of structured packing that is usually used for conventional distillation (e.g. Sulzer $\mathrm{BX}^{\circledR}$ ) (Heils et al., 2014). It is also possible to immobilize enzymes in form of enzyme-beads, but there was no effect of US on enzyme activity observed for this type of immobilization (Wierschem et al., 2017).

\section{Problem Statement}

Combining enzymatic reaction and distillation in form of ERD facilitates an in-situ product removal, which circumvents the conversion limitation of the enzymatic reaction. While the implementation of the transesterification of EtBu in ERD has been reported, investigated and demonstrated on pilot-scale (Wierschem et al., 2016b) the assessment of beneficial effects of 
1 US application on the reaction rate of the transesterification has so far only been demonstrated

2 in lab-scale reaction experiments (Wierschem et al., 2017b). In order to analyze if the 3 combination of both techniques in form of US-ERD bears the potential to further increase reaction rates and improve the ERD, the current study presents a model-based analysis of the performance of ERD without US and US-ERD. Therefore, we have defined a case study in which the minimum total annual costs (TAC) of the US-ERD column, for a production capacity of 10 kiloton of $\mathrm{BuBu}$ per year with a purity specification of $99 \mathrm{wt} \%$ have to be determined for an annual operation of 8000 hours. The basis of the techno-economic evaluation is a validated ERD model (Wierschem et al., 2016b) extended by cost functions, where US-assisted enzymatic reaction kinetics are implemented (Wierschem et al., 2017). An objective function is minimized to yield for the lowest TAC. Note that commercial US equipment applied to distillation is currently not available, therefore assumptions for equipment costs and design are provided by Smart Material Corp., a technology supplier of US equipment.

\section{Cost Estimation}

The cost calculations for the ERD process include the column shell, condenser, reboiler, packing and enzyme costs, US equipment costs, as well as utilities (e.g. steam, electricity). Investment costs are annualized based on assumed interest rate and operating time and cost estimates are updated on the basis of economic cost indices to the year 2014. Table 1 provides the basis of cost estimation for equipment and utilities. The key economic performance indicators used are the total investment costs (TIC), total operating costs (TOC), and TAC. The detailed calculation of the TIC and TOC for the equipment is presented in the Supplementary data, Section A.

As US equipment does not exist for reactive distillation columns, we assume that US transducer have a diameter of 2-3 cm, and three of them are connected to one power amplifier. It is further assumed that all the ingoing power into the amplifier equals the outgoing power into the liquid volume. Our assumption is also that one transducer is used to impinge a liquid volume of $0.5 \mathrm{~L}$ with $50 \mathrm{~W}$ as used in the reaction kinetics investigation (Wierschem et al., 2017). Depending on the liquid hold-up in the reactive section of the column the numbers of transducer and power amplifiers are calculated.

The volume fraction of enzyme per cubic meter packing is scaled-up from the pilot-scale column and amounts to $31.82 \mathrm{~kg} / \mathrm{m}^{3}$ of column volume. In our previous validation experiments there was no loss in activity observed for enzyme beads after 200 hours of 
1 operation (Wierschem et al., 2016b). With these results, a prediction of the enzyme stability over a period of one year is not legitimate. On top pf that, other studies show long-term enzyme stability. Heils et al. (2012) showed a stable coated packing after an initial washing step over a long period. Hama et al. (2011) showed long-term stability of CalB for about ten months and Anderson et al. (1998) regarded enzymes as stable for several thousand hours, which underlines our assumption that the enzyme can be stable for one year. For the optimization an activity loss of the enzyme is neglected and it remains the same activity for the period of one year. The costs of enzyme entrapped in coated packing, which is not commercially available, are assumed to be as high as the costs for the enzyme beads IMMCALB-T2-1000XL from ChiralVision B.V., The Netherlands, at $20 \mathrm{~kg}$ and $100 \mathrm{~kg}$ scale (see Table 1). The same amount needed for coated packing is assumed to have the same price as for the enzyme beads. The price for $20 \mathrm{~kg}$ and $100 \mathrm{~kg}$ of enzyme beads are known and a linear cost function was used to calculate prices in between. For higher scales up to $300 \mathrm{~kg}$ the price per ton is proposed to be the similar as for $100 \mathrm{~kg}$.

\section{Results and Discussion}

Aspen Custom Modeler ${ }^{\circledR}$ was used for the rate-based simulations of the ERD process, based on the recently developed and experimentally validated model (Wierschem et al., 2016b). The modified UNIFAC (Dortmund) model (UNIF-DMD) was used as most suitable property model for modeling the activity coefficients of the chemical system of the transesterification of ethyl butyrate. More detailed information on the thermodynamic model is available in previous work (Heils et al., 2014). The kinetics for the (US-assisted) enzymatic reaction is taken from our earlier work (Wierschem et al., 2017). For the enzyme coated packing a reduced ordered bi bi kinetic approach was employed for both, the kinetics without US and the kinetics with US assistance - see Eq. (2). It accounts for substrate inhibition by $\mathrm{BuOH}$ according to Bisswanger (Bisswanger, 2008). The kinetic parameters for the kinetics without US are presented in Table 2 and the ones for the US-assisted kinetics in Table 3. For the USassisted kinetics $v_{\max }$ is lower compared to the kinetics without US but the lower value of $K_{i, \mathrm{BuOH}}$ compensates for the lower $v_{\max }$, so that the reaction rates are higher for substrate ratios of $\mathrm{EtBu}$ over $\mathrm{BuOH}$ higher than 2.

$$
v=\frac{v_{\max } \cdot[\mathrm{BuOH}][\mathrm{EtBu}]}{K_{i, B u O H} \cdot[E t B u]+K_{m, E t B u} \cdot[\mathrm{BuOH}]+K_{m, B u O H} \cdot[E t B u]+[B u O H][E t B u]}
$$


1 The production capacity and the purity specifications are set as fixed variables. Instead of those two,

2 the feed stream and the substrate ratio were set free. The according optimization problem is 3 solved by means of an evolutionary algorithm described in the literature (Keller et al., 2013).

4 In order to account for various constraints that are not included in the simulation model, the objective function is represented by a sum of the TAC and additional penalty functions (see Eq. (3)). The penalty functions account for constraint violations according to process specifications or fluid dynamic considerations that need to be met. Penalty1 is given by Eq. (11) and addresses the maximum temperature limit of the enzyme (in K). Fluid dynamic operation limits are considered by Eq. (5) and (6), taking into account that the range for the $F$ factor lies between $0.2 \sqrt{\mathrm{Pa}}$ and $2.5 \sqrt{\mathrm{Pa}}$ and the maximum $F$-factor is set to $2 \sqrt{\mathrm{Pa}}$ and the liquid load liq_load $\min$ should be higher than the value of $0.05 \mathrm{~m}^{3} / \mathrm{m}^{2} / \mathrm{h}$ (Bravo et al., 1985; Goedecke, 2006; Keller et al., 2013; Sulzer Chemtech Ltd, 2003).

$$
\begin{aligned}
& \min \text { Objective function }=\min \left(\mathrm{TAC}+\sum \text { penalty }\right) \\
& \text { penalty } 1= \begin{cases}9999999, & \text { if } T_{\max , \text { enzyme }}>343 \\
0, & \text { if } T_{\max , \text { enzyme }} \leq 343\end{cases}
\end{aligned}
$$

penalty $2=\left\{\begin{array}{l}\mathrm{TAC}+\mathrm{TAC} \cdot\left(\left(\mathrm{F}-\text { factor }_{\text {min }}-0.2\right) / 0.2\right)^{2}, \text { if } \mathrm{F}-\text { factor }_{\text {min }}<0.2 \\ 0, \text { if F-factor }{ }_{\min } \geq 0.2\end{array}\right.$

$$
\text { penalty } 3=\left\{\begin{array}{l}
\text { TAC }+ \text { TAC } \cdot((\text { liq_load } \\
\text { min } \\
\left.\left.0, \text { if liq_load }{ }_{\text {min }} \geq 0.05\right) / 0.05\right)^{2}, \text { if liq_load }{ }_{\text {min }}<0.05
\end{array}\right.
$$

The minimization of the objective function is a minimization of the TAC (description of its calculation is within the Supplementary data, Section A) and the above mentioned penalties. The equality constraints are provided by the rate-based model within the simulation software of Aspen Custom Modeler ${ }^{\circledR}$. The design degrees of freedom, which are manipulated by the optimization algorithm, are the reflux ratio $(R R)$, the distillate-to-feed-ratio $(D / F)$, the column head pressure $p_{\text {Head }}$ and the height of each section ( $\left.h_{\text {Section }}\right)$ whereby Section1, Section 2 and Section3 denote the rectifying section, the reactive section and the stripping section, respectively. Their boundaries are given in Table 4 and Table 5 and a graphical explanation of the free, fixed and manipulated variables of the optimization problem is provided by Figure 2 . The number of individuals per generation, is 10 and the three individuals with the lowest objective function are used to determine the parameters of the next generation by mutation 
1 and recombination. Table 6 provides the control parameters of the evolutionary algorithm used for our optimization studies. The optimization is terminated if no improvement of the objective function is achieved within 20 consecutive generations.

Note that, the complex process model, accounting for mass transfer, thermodynamic and economic models, results in a highly non-linear optimization problem, which is not only hard to solve, but is likely to have multiple locally optimal solutions. Especially the evaluation of the single individuals requires advanced measures to improve convergence properties of the single simulations. Thus, in order to increase the computational robustness the evaluation of a single individual for a new vector of design variables is generated as follows. A converged snapshot with an initial solution is saved and imported prior to each optimization run. From there a homotopy approach is used to continually transpose the decision variables of the present individual. In case the homotopy approach does not converge the snapshot is imported again and the individual is discarded by setting a high value for the objective function. When a run did converge the value of the objective function is sent back to the EA, which selects the 'fittest' individuals to proceed with as described by Keller et al. (2013). Convergence of the optimization by means of the evolutionary algorithm was achieved in reasonable time over a reasonable number of a few hundred generations. In case of more complex optimization problems with an increased number of decision variables a hybrid optimization method as e.g. presented by Urselmann et al. (2015) and Skiborowski et al. (2015) should be considered to improve the performance of the optimization.

\subsection{ERD optimization}

In this section the results of the optimization of the ERD process without US are discussed. Table 4 lists the decision variables, the lower/upper bounds of each variable, as well as the optimized values. Figure 3 shows the composition and temperature profiles along the ERD column for the optimized design. In terms of performance, the ERD process without US is characterized by $97.4 \%$ conversion of $\mathrm{BuOH}, 80.4 \%$ conversion of $\mathrm{EtBu}, 99.0 \mathrm{wt} \%$ purity of $\mathrm{BuBu}$ in the bottom stream $(1250.0 \mathrm{~kg} / \mathrm{h})$, and $61.4 \mathrm{wt} \%$ purity of EtOH in the top stream $(644.0 \mathrm{~kg} / \mathrm{h})$. The head pressure is at $15 \mathrm{kPa}$ corresponding to the maximum temperature allowed due to the thermal instability of the enzymatic catalyst. The pressure drop over the column height is $1.3 \mathrm{kPa}$. The rectifying section is small $(0.3 \mathrm{~m})$ as the separation between $\mathrm{EtBu}$ and $\mathrm{EtOH}$ is easy within the concentration range up to the distillate composition of $61.4 \mathrm{wt} \%$ of EtOH as the vapor-liquid-equilibrium verifies (Supplementary data, Section B). The height of the reactive and stripping section is $4.1 \mathrm{~m}$ and $3.0 \mathrm{~m}$ respectively, resulting in a 
1 total column height of $7.4 \mathrm{~m}$, and a column diameter of $1.39 \mathrm{~m}$. The substrate ratio is $2 \mathrm{EtBu}: \mathrm{BuOH}=1.21$ and the total feed stream is $1894.0 \mathrm{~kg} / \mathrm{h}$. That leads to the following 3 TIC $_{\text {Plant }}$ and TOC $_{\text {Plant }}$ that are summarized in Figure 4 with their partial cost contribution.

4 The value of the objective function, which is the TAC, amounts to $18.41 \mathrm{M} € / \mathrm{yr}$ and all penalty functions are equal to zero. The $\mathrm{TIC}_{\text {Plant }}$ amount to $2.53 \mathrm{M} €$ so that the annuity is $361000 € / \mathrm{yr}$. The $\mathrm{TOC}_{\text {Plant }}$ amount to $18.05 \mathrm{M} € / \mathrm{yr}$ and are 50 times larger than the annuity. Figure 4 shows the shares of the considered items for the annuity and the TOC without raw material costs $(\mathrm{RM})$. The main cost driver is the raw material costs, which exhibit a share of $98 \%$ of the $\mathrm{TOC}_{\text {Plant }}$. Consequently, the investment costs are of minor importance compared to the operating costs. For convenience, Figure 5 shows the objective function values for each optimized generation and the 10 different individuals leading to the optimized solution.

\subsection{US-ERD optimization}

Table 5 lists the decision variables, the lower/upper bounds of the acceptable range, as well as the optimized values for the US-ERD process. Figure 6 shows the composition and temperature profiles over the column height of the US-ERD for the optimal run.

The conversion is practically the same as in the case of ERD without US and the values are $98.0 \%$ conversion of $\mathrm{BuOH}$ and $82.0 \%$ conversion of EtBu. The leaving streams exhibit a purity of $\mathrm{BuBu}$ of $99.0 \mathrm{wt} \%$ with $1250.0 \mathrm{~kg} / \mathrm{h}$ in the bottom and a purity of EtOH of $64.2 \mathrm{wt} \%$ with $615.7 \mathrm{~kg} / \mathrm{h}$ in the distillate, which is slightly purer as in the ERD without US. The pressure is at $15 \mathrm{kPa}$ as in the ERD without US and the total column height is $6.9 \mathrm{~m}$ with a diameter of $1.34 \mathrm{~m}$ and therefore, the column is smaller than in the ERD case. Due to the higher reaction rate for the US-assisted ERD, as compared to ERD, a smaller reactive section height $(3.6 \mathrm{~m}$ compared to $4.1 \mathrm{~m})$ is needed The rectifying section is $0.6 \mathrm{~m}$ high and the stripping section is smaller for US-ERD compared to ERD (2.7 m compared to $3.0 \mathrm{~m}$ ), since the exiting stream from the reactive section is closer to the fixed bottom purity. The substrate ratio is $\mathrm{EtBu}: \mathrm{BuOH}=1.19$ and the total feed stream is $1865.7 \mathrm{~kg} / \mathrm{h}$.

The cost contributions for the US-ERD are summarized in Figure 7. The objective function amounts to $18.45 \mathrm{M} € / \mathrm{yr}$, while the penalties are zero. The $\mathrm{TIC}_{\text {Plant }}$ result in $3.17 \mathrm{M} €$ and accordingly the annuity amounts to $451000 € / \mathrm{yr}$. The $\mathrm{TOC}_{\text {Plant }}$ again have the highest cost share with $18.00 \mathrm{M} € / \mathrm{yr}$ with $17.62 \mathrm{M} € / \mathrm{yr}$ for the raw materials. For completeness, Figure 8 shows the resulting objective function for each optimized generation. Notably, both processes, ERD and US-ERD, result in very similar costs. The objective function of the US-ERD is higher by $40000 € / \mathrm{yr}$ compared to the ERD. The difference of the 
1 processes is that the US-ERD exhibits higher installation costs, this being mainly driven by

2 higher US equipment costs, and lower operating costs due to a smaller reactive section.

3 A volume of approximately $387 \mathrm{~L}$ is impinged with US, which indicates that 773 transducer 4 and hence 258 amplifiers are necessary. This results in an annuity of the US equipment of $131000 € / y r$, and a total of $38.7 \mathrm{~kW}$ power input. These assumptions are subject to high uncertainty and however, based on these assumptions the US-ERD is not advantageous compared to the ERD.

A uniform distribution of the US field is essential for an accurate operation. Fluctuations in the US field can lead to an uneven acceleration of the enzymes and therefore influence the reaction rates. An US field in the distillation column might not be uniformly applied without equipment testing. A proposal to avoid testing of new equipment could be the usage of commercially available devices as side reactors that guarantee a uniform distribution of the US field.

\subsection{Economic Sensitivity}

Literature references show that for various chemical systems further improvement in reaction rate acceleration by US application is possible.(Alves et al., 2014; Gharat and Rathod, 2013; Khan and Rathod, 2015; Thompson and Doraiswamy, 1999) To find out how an increase in reaction rates influences the costs of the US-ERD we introduced a reaction enhancement factor to the US-assisted kinetics in order to further accelerate the reaction rates, and checked by sensitivity analysis the impact of faster reaction rates on the costs. A higher reaction rate accounts for a smaller reactive section, leading to less enzyme usage and less US equipment lowering the TIC and thereby also the TAC of the US-ERD. Conversion is kept constant compared to the US-ERD scenario previously described, while only the height of the reactive section is changing. Figure 9 shows that at higher reaction rates, the height of the reactive section and the TIC of the process are significantly reduced. However, the TOC are nearly unaffected, such that the reduction in TAC can nearly completely be attributed to the reduced annuity, although the TAC are only minimally affected. The costs of the US equipment as well as packing and enzyme costs are reduced due to the decreased height of the reactive section. Already at a reaction factor of 1.11 the TAC of the US-ERD supersedes the ERD as the cost beneficial process option. Further improvements, which have been reported for other and Rathod, 2013; Khan and Rathod, 2015) 
1 The uncertainty in costing of the US equipment necessitates a sensitivity analysis, which 2 represents an investigation of the impact of US equipment costs on the TAC. Therefore, the total investment costs for bare US equipment, TIC_US, are varied from $100000 €$ to 1 Million $€$ (Figure 10). The costs of bare US equipment for the optimized US-ERD scenario amount to approximately $220000 €$. As Figure 10 shows, the impact of the US equipment costs on the TAC is rather small. A more than fourfold increase in the TIC_US from $220000 €$ to 1 Million $€$ leads to a $2.5 \%$ increase in the TAC. The TIC for the process increase significantly, but they only have a small share to the TAC. Hence, only a minor impact of the US equipment costs on the TAC is observable.

\section{Conclusion}

The ultrasound-assisted Enzymatic Reactive Distillation (US-ERD) proposed here features faster reaction rates that lead to a $12 \%$ smaller reactive section of the distillation column compared to the ERD without US and a 7\% smaller total column height. The technoeconomic evaluation shows that the US-ERD process requires a $25 \%$ higher annuity, at slightly lower total operating costs. The total operating costs per year, of which $98 \%$ amount to the material costs, are 43 times higher than the annuity, translated ultimately into practically equal total annual costs (TAC), as in the case of the ERD alternative. Installation costs of the US equipment are compensated by lower reactive section height and therefore less costs for enzyme. Nonetheless, a higher increase in the reaction rate by improved ultrasound application would lead to significant cost advantages. Sensitivity analysis shows that if the reaction rates could be further increased by US investment costs can be lowered.

\section{Acknowledgements}

25 The research leading to these results has received funding from the European Community's 26 Seventh Framework Programme under grant agreement no. FP7-NMP-2012-309874. The authors are grateful to Jan Kunzmann (Smart Material Corp.) for providing cost estimates of US equipment design for an industrial distillation process. 


\section{References}

Alves, J.S., Garcia-Galan, C., Schein, M.F., Silva, A.M., Barbosa, O., Ayub, M.A.Z., Fernandez-Lafuente, R., Rodrigues, R.C., 2014. Combined effects of ultrasound and immobilization protocol on butyl acetate synthesis catalyzed by CALB. Molecules. 19(7), $9562-76$

Bisswanger H., 2008. Enzyme kinetics: Principles and methods. 2nd ed., Wiley-VCH, Weinheim

Bravo, J.L., Rocha, J.A., Fair, J.R., 1985. Mass transfer in gauze packings. Hydrocarbon Process. 64(1), 91-5

Gharat, N., Rathod, V.K., 2013. Ultrasound assisted enzyme catalyzed transesterification of waste cooking oil with dimethyl carbonate. Ultrason. Sonochem. 20(3), 900-5

Goedecke R., 2006. Fluidverfahrenstechnik: Grundlagen, Methodik, Technik, Praxis, Wiley$\mathrm{VCH}$, Weinheim

Górak, A., Hoffmann, A., 2001. Catalytic distillation in structured packings: Methyl acetate synthesis. AIChE J. 47(5), 1067-76

Górak, A., Stankiewicz, A., 2011. Intensified reaction and separation systems. Annu. Rev. Chem. Biomol. Eng. 2, 431-51

Heils, R., Jensen, J.-H., Wichert, S., Behrens, N., Fabuel-Ortega, M., Liese, A., Smirnova, I., 2015. Enzymatic Reactive Distillation: Kinetic Resolution of rac-2-Pentanol with Biocatalytic Coatings on Structured Packings. Ind. Eng. Chem. Res. 54(38), 9458-67

Heils, R., Niesbach, A., Wierschem, M., Claus, D., Soboll, S., Lutze, P., Smirnova, I., 2014. Integration of Enzymatic Catalysts in a Continuous Reactive Distillation Column: Reaction Kinetics and Process Simulation. Ind. Eng. Chem. Res. 53, 19612-9

Heils, R., Sont, A., Bubenheim, P., Liese, A., Smirnova, I., 2012. Integration of Enzymatic Catalysts in a Reactive Distillation Column with Structured Packings. Ind. Eng. Chem. Res. 51(35), 11482-9

Keller, T., Dreisewerd, B., Górak, A., 2013. Reactive Distillation for Multiple-Reaction Systems: Optimisation Study Using an Evolutionary Algorithm. Chem. Process Eng. 34(1)

Khan, N.R., Rathod, V.K., 2015. Enzyme catalyzed synthesis of cosmetic esters and its intensification: A review. Process Biochem. 50(11), 1793-806

Liu, H.Z., Liang, X.F., Yang, L.R., Chen, J.Y., 2010. Challenges and innovations in green process intensification. Sci. China Chem. 53(7), 1470-5 
1 Lutze, P., Górak, A., 2013. Reactive and membrane-assisted distillation: Recent developments and perspective. Chem. Eng. Res. Des. 91(10), 1978-97

Lutze, P., Román-Martinez, A., Woodley, J.M., Gani, R., 2012. A systematic synthesis and design methodology to achieve process intensification in (bio) chemical processes. Comput. Chem. Eng. 36, 189-207

Lutze, P., Sudhoff, D; 2016. Introduction to process intensification, in: Lutze, P., Górak, A. (Eds.), Reactive and Membrane-Assisted Separations. De Gruyter, Berlin/Boston, pp. 136

Luyben W.L., 2011. Principles and case studies of simultaneous design, Wiley, Hoboken, N.J. Lye, G., Woodley, J.M., 1999. Application of in situ product-removal techniques to biocatalytic processes. Trends Biotechnol. 17(10), 395-402

Niesbach, A., Kuhlmann, H., Keller, T., Lutze, P., Górak, A., 2013. Optimisation of industrial-scale n-butyl acrylate production using reactive distillation. Chem. Eng. Sci. $100,360-72$

Paiva, A.L., van Rossum, D., Malcata, F.X., 2003. Lipase-Catalyzed Synthesis of Butyl Butyrate by Alcoholysis in an Integrated Liquid-Vapor System. Biotechnol. Prog. 19(3), $750-4$

Schmidt-Traub H., Górak A., 2006. Integrated reaction and separation operations: Modelling and experimental validation, Springer, Berlin

Schneider, R., Noeres, C., Kreul, L.U., Górak, A., 2001. Dynamic modeling and simulation of reactive batch distillation. Comput. Chem. Eng. 25(1), 169-76

Shah, M., Kiss, A.A., Zondervan, E., de Haan, A. B., 2012. A systematic framework for the feasibility and technical evaluation of reactive distillation processes. Chem. Eng. Process. Process Intensif. 60, 55-64

Skiborowski, M., Rautenberg, M., Marquardt, W., 2015. A Hybrid EvolutionaryDeterministic Optimization Approach for Conceptual Design. Ind. Eng. Chem. Res. 54(41), 10054-72

Sulzer Chemtech Ltd, 2003. Structured packings for distillation, absorption and reactive distillation

Thompson, L.H., Doraiswamy, L.K., 1999. Sonochemistry: Science and Engineering. Ind. Eng. Chem. Res. 38(4), 1215-49

Urselmann, M., Engell, S., 2015. Design of memetic algorithms for the efficient optimization of chemical process synthesis problems with structural restrictions. Comput. Chem. Eng. $72,87-108$ 
1 Wierschem, M., Boll, S., Lutze, P., Górak, A., 2016a. Evaluation of the Enzymatic Reactive 2 Distillation for the Production of Chiral Compounds. Chem. Ing. Tech. 88(1-2), 147-57

3 Wierschem, M., Schlimper, S., Heils, R., Smirnova, I., Kiss, A.A., Skiborowski, M., Lutze, 4 P., 2016b. Pilot-scale validation of Enzymatic Reactive Distillation for butyl butyrate 5 production. Chem. Eng. J. 312, 106-17

6 Wierschem, M., Walz, O., Mitsos, A., Termuehlen, M., Specht, A.L., Kissing, K., 7 Skiborowski, M., 2017. Enzyme kinetics for the transesterification of ethyl butyrate with 8 enzyme beads, coated packing and ultrasound assistance. Chem. Eng. Process. Process 9 Intensif. $111,25-34$ 


\section{Tables}

3 Table 1. Cost basis for installation and operation

\begin{tabular}{|c|c|c|c|}
\hline Variable & Costs & Unit & Reference \\
\hline \multicolumn{4}{|l|}{ Ultrasound (US) } \\
\hline Transducer & 120 & $€ /$ piece & Smart Material Corp., Germany \\
\hline Power amplifier & 500 & $€ /$ piece & Smart Material Corp., Germany \\
\hline \multicolumn{4}{|l|}{ Utilities } \\
\hline Electricity & 12.35 & $€ / G J$ & Luyben, 2011 (Luyben, 2011) \\
\hline Steam (6 bar) & 7.78 & \$/GJ & Luyben, 2011 (Luyben, 2011) \\
\hline Steam (42 bar) & 9.88 & \$/GJ & Luyben, 2011 (Luyben, 2011) \\
\hline Cooling water & 0.05 & $\$ / \mathrm{t}$ & Luyben, 2011 (Luyben, 2011) \\
\hline \multicolumn{4}{|l|}{ Catalyst } \\
\hline Enzyme (100 kg scale) & 900 & $€ / \mathrm{kg}$ & ChiralVision B.V., The Netherlands \\
\hline Enzyme (20 kg scale) & 1400 & $€ / \mathrm{kg}$ & ChiralVision B.V., The Netherlands \\
\hline \multicolumn{4}{|l|}{ Substrate } \\
\hline $\mathrm{BuOH}$ & 627.8 & $€ / t$ & $\begin{array}{l}\text { Niesbach et al., } 2013 \text { (Niesbach et al., } \\
\text { 2013) }\end{array}$ \\
\hline $\mathrm{EtBu}$ & 2019 & $\$ / t$ & $\begin{array}{l}\text { Sunlong Industrial \& Trading Ltd., } \\
\text { China }\end{array}$ \\
\hline
\end{tabular}

9 Table 2. Kinetic parameters for coated packing kinetic model without US

\begin{tabular}{ccc}
\hline Parameter & Value & Unit \\
\hline$v_{\max }$ & 0.668 & {$\left[\mathrm{~mol} /\left(\mathrm{s} \cdot \mathrm{kg}_{\text {cat }}\right]\right.$} \\
$\mathrm{K}_{\mathrm{m}, \mathrm{BuOH}}$ & 0 & {$[\mathrm{~mol} / \mathrm{l}]$} \\
$\mathrm{K}_{\mathrm{m}, \mathrm{EtBu}}$ & 25.252 & {$[\mathrm{~mol} / \mathrm{l}]$} \\
$\mathrm{K}_{\mathrm{i}, \mathrm{BuOH}}$ & 0.054 & {$[\mathrm{~mol} / \mathrm{l}]$} \\
\hline
\end{tabular}


2 Table 3. Kinetic parameters for coated packing US-assisted kinetic model

\begin{tabular}{ccc}
\hline Parameter & Value & Unit \\
\hline$v_{\max }$ & 0.509 & {$\left[\mathrm{~mol} /\left(\mathrm{s} \cdot \mathrm{kg}_{\text {cat }}\right)\right]$} \\
$\mathrm{K}_{\mathrm{m}, \mathrm{BuOH}}$ & 0 & {$[\mathrm{~mol} / \mathrm{l}]$} \\
$\mathrm{K}_{\mathrm{m}, \mathrm{EtBu}}$ & 25.256 & {$[\mathrm{~mol} / \mathrm{l}]$} \\
$\mathrm{K}_{\mathrm{i}, \mathrm{BuOH}}$ & 0.007 & $\mathrm{~mol} / 1$ \\
\hline
\end{tabular}

3

4

5

6

7

8

9

10

11

12

13

14

15

16 Table 4. Optimization variables for the ERD process without US

\begin{tabular}{lllll}
\hline Decision variables & Lower Bound & Upper Bound & Optimal Value & Unit \\
\hline Reflux ratio & 2.0 & 8.0 & 5.6 & {$[\mathrm{~kg} / \mathrm{kg}]$} \\
Distillate-to-feed-ratio & 0.30 & 0.70 & 0.34 & {$[\mathrm{~kg} / \mathrm{kg}]$} \\
$\mathrm{h}_{\text {Section1 }}$ & 0.1 & 0.5 & 0.3 & {$[\mathrm{~m}]$} \\
$\mathrm{h}_{\text {Section2 }}$ & 2.0 & 8.0 & 4.1 & {$[\mathrm{~m}]$} \\
$\mathrm{h}_{\text {Section3 }}$ & 0.1 & 4.0 & 3.0 & {$[\mathrm{~m}]$} \\
$\mathrm{p}_{\text {Head }}$ & 0.13 & 0.18 & 0.15 & {$[\mathrm{kPa}]$} \\
\hline
\end{tabular}

17 
2 Table 5. Optimization variables for the US-ERD process

\begin{tabular}{lllll}
\hline Decision variables & Lower Bound & Upper Bound & Optimal Value & Unit \\
\hline Reflux ratio & 2.0 & 8.0 & 5.3 & {$[\mathrm{~kg} / \mathrm{kg}]$} \\
Distillate-to-feed-ratio & 0.30 & 0.70 & 0.33 & {$[\mathrm{~kg} / \mathrm{kg}]$} \\
$\mathrm{h}_{\text {Section1 }}$ & 0.1 & 0.8 & 0.6 & {$[\mathrm{~m}]$} \\
$\mathrm{h}_{\text {Section2 }}$ & 2.0 & 8.0 & 3.6 & {$[\mathrm{~m}]$} \\
$\mathrm{h}_{\text {Section3 }}$ & 0.1 & 4.0 & 2.7 & {$[\mathrm{~m}]$} \\
$\mathrm{p}_{\text {Head }}$ & 0.13 & 0.18 & 0.15 & {$[\mathrm{kPa}]$} \\
\hline
\end{tabular}

3

4

5

6

7

8

9

10

11

12

13

14

15

16 Table 6. Control parameters of the evolutionary algorithm

\begin{tabular}{lcccc}
\hline Control parameter & $\mathbf{1}^{\text {st }}$ phase & $\mathbf{2}^{\text {nd }}$ phase & $\mathbf{3}^{\text {rd }}$ phase & $\mathbf{4}^{\text {th }}$ phase \\
\hline Generation to change phase & 90 & 150 & 200 & - \\
Intermediate recombination & 0.2 & 0.5 & 0 & 0.5 \\
probability & & & & \\
Global mutation probability & 0.7 & 0.3 & 0 & 0.1 \\
Local mutation probability & 0.7 & 0.3 & 0.9 & 0.1 \\
Local mutation radius & 1.00 & 0.50 & 0.10 & 0.01 \\
\hline
\end{tabular}

17 


\section{Figures}

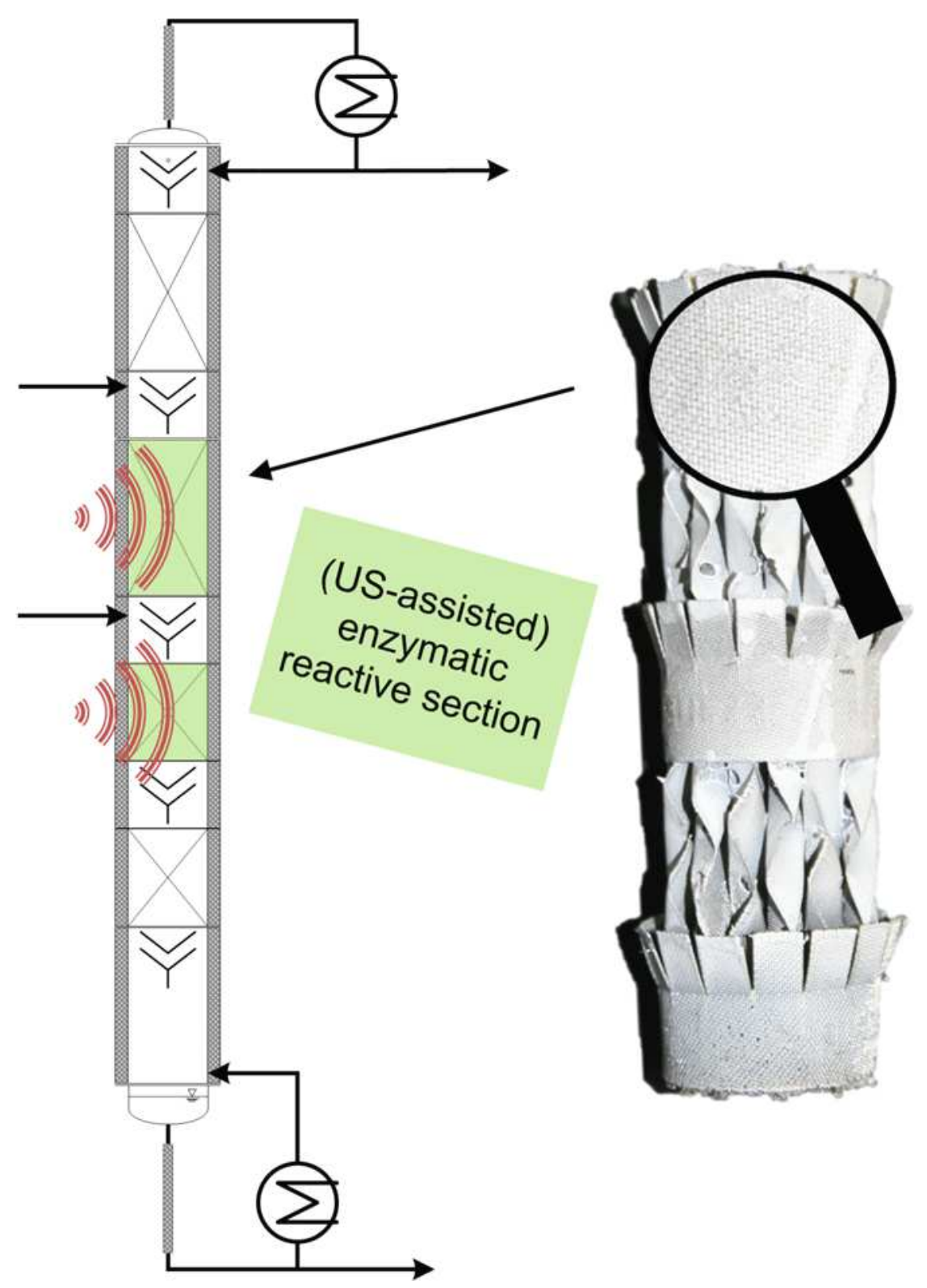

Figure 1. Scheme of the US-ERD process with the enzyme coated packing placed in the USassisted reactive section.

(




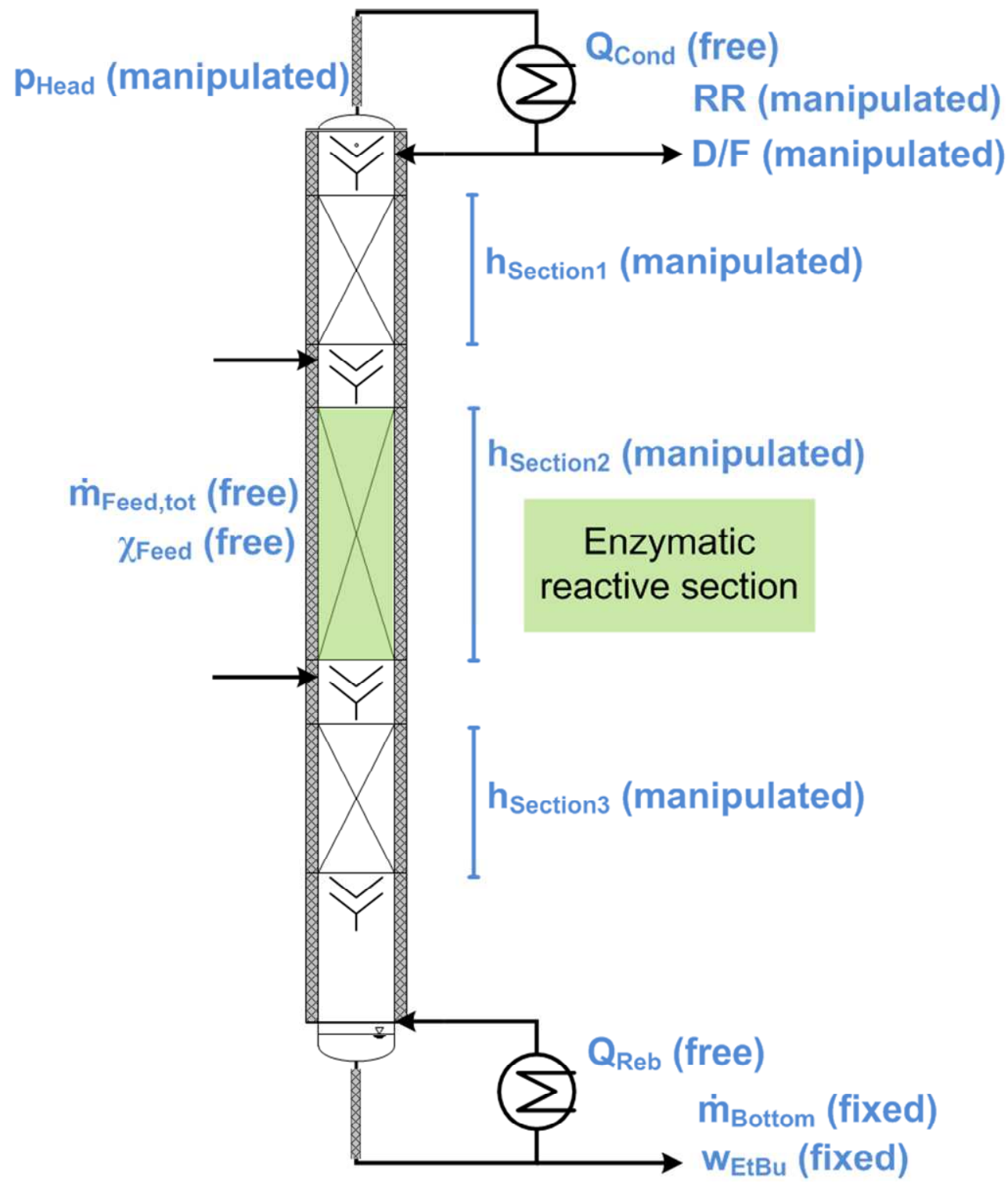

4 Figure 2. Manipulated variables of the optimization. The total feed stream $\left(\mathrm{m}_{\text {Feed,tot }}\right)$ and the 5 substrate ratio $\left(\chi_{\text {Feed }}\right)$ are set free and therefore the bottom stream $\left(\mathrm{m}_{\text {Bottom }}\right)$ and the bottom 6 mass fraction $\left(\mathrm{w}_{\mathrm{EtBu}}\right)$ are fixed. The reboiler and condenser duties $\left(\mathrm{Q}_{\mathrm{Reb}}\right.$ and $\left.\mathrm{Q}_{\mathrm{Cond}}\right)$ are free variables, whereas the reflux ratio (RR) and the distillate-to-feed-ratio (D/F) are fixed and manipulated within the optimization. 

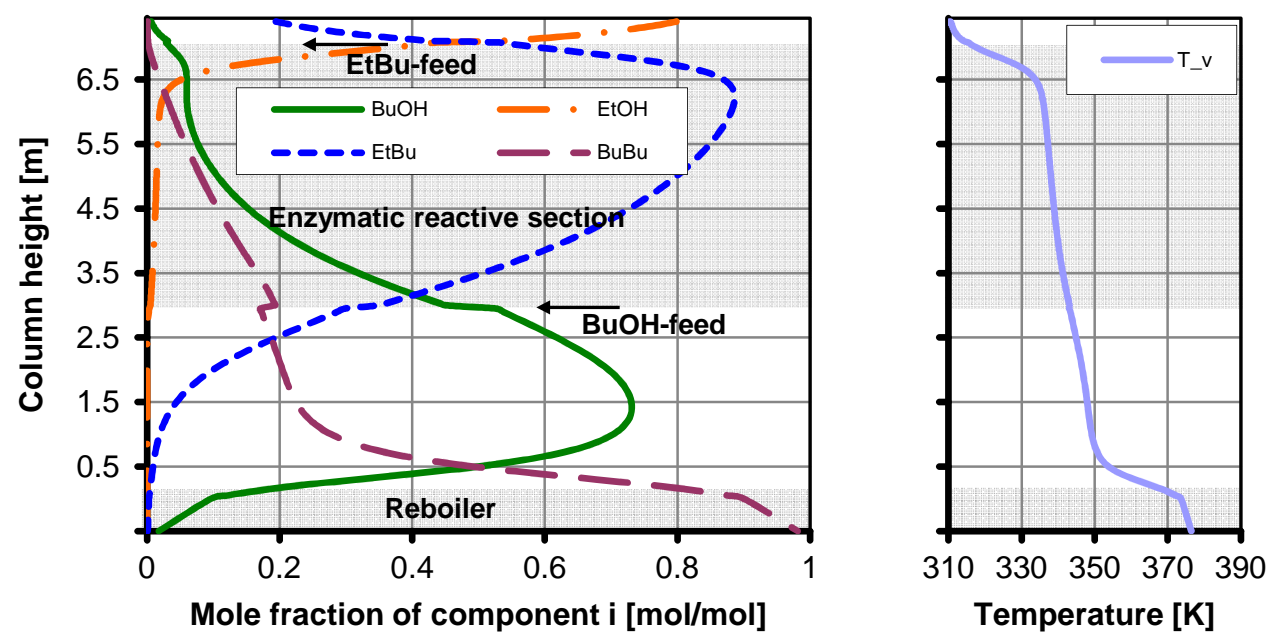

Figure 3. Simulated profiles: liquid molar fractions (left) and liquid temperature (right) for the ERD column without US with enzyme coated packing. ( 6
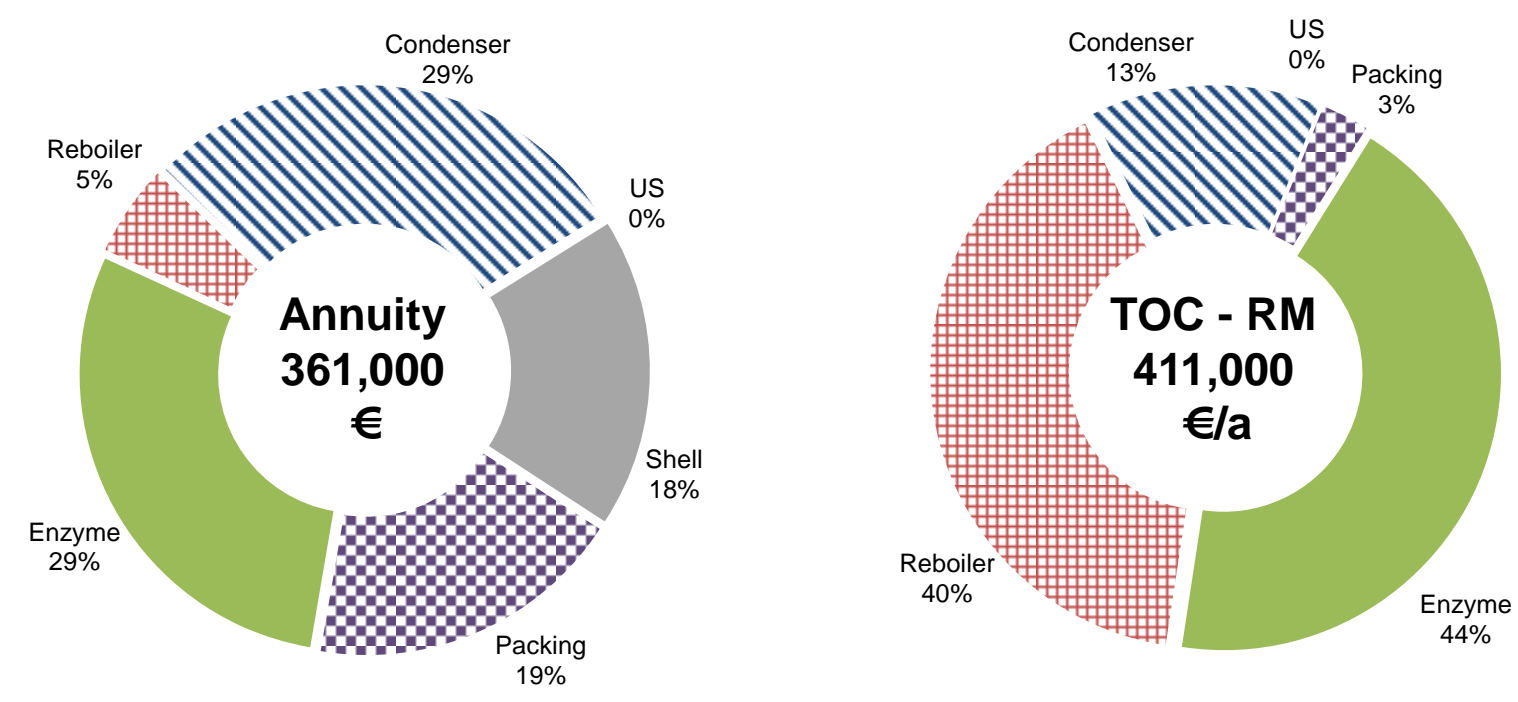

$\mathrm{RM}=17,64$ Mio. $€ / \mathrm{yr}$

Figure 4. Total investment cost (TIC) and total operating cost (TOC) without raw material costs (RM) of the optimized ERD process without US. 


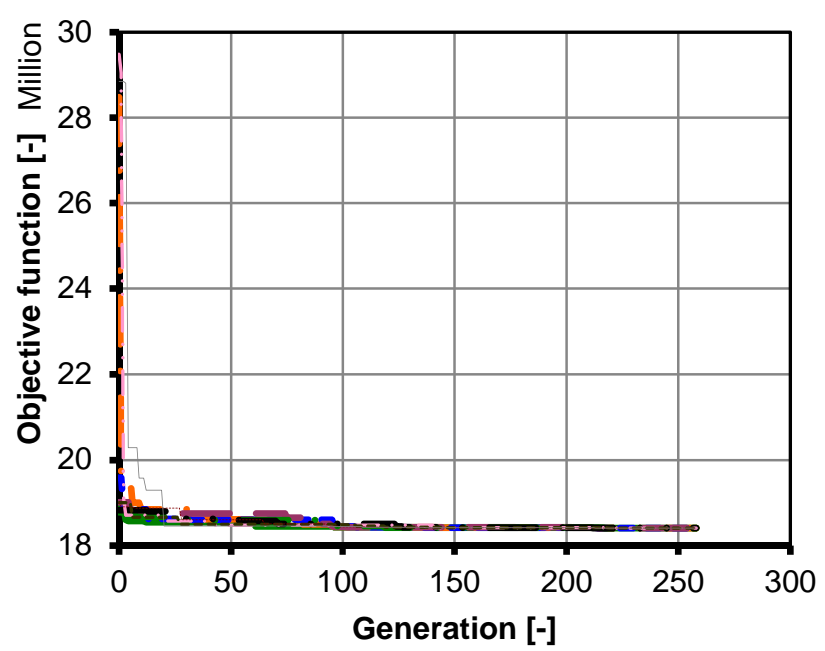

Figure 5. Objective function values dependency on the generations, during the optimization run of the ERD process without US.
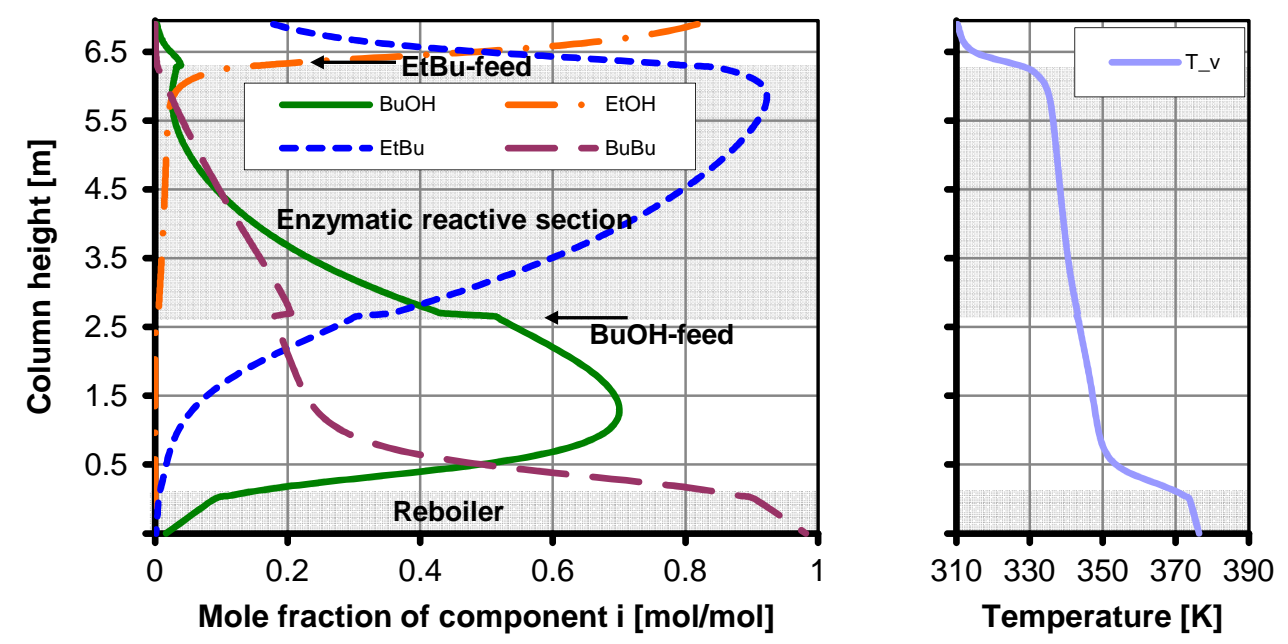

Figure 6. Simulated profiles: liquid molar fractions (left) and liquid temperature (right) for the US-ERD column with enzyme coated packing. 


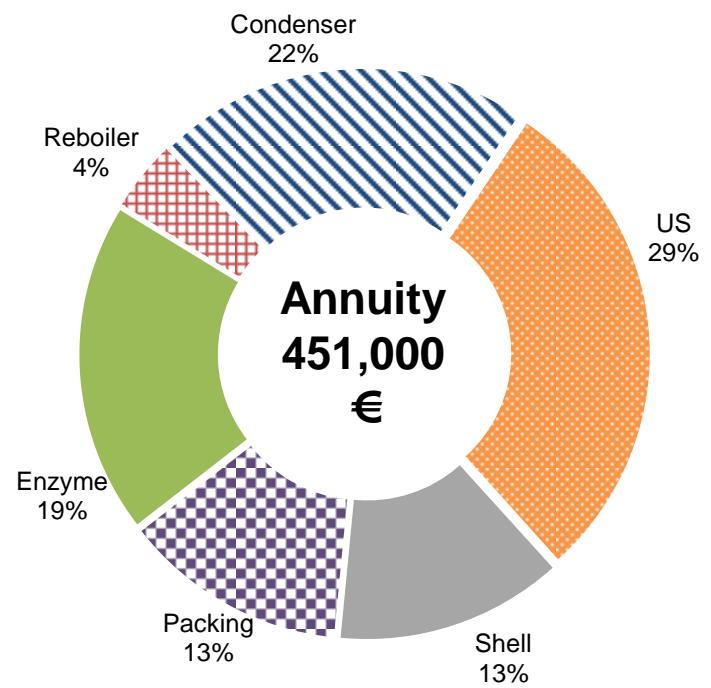

2

10

11 Figure 8. Objective function values dependency on the generations, during the optimization 12

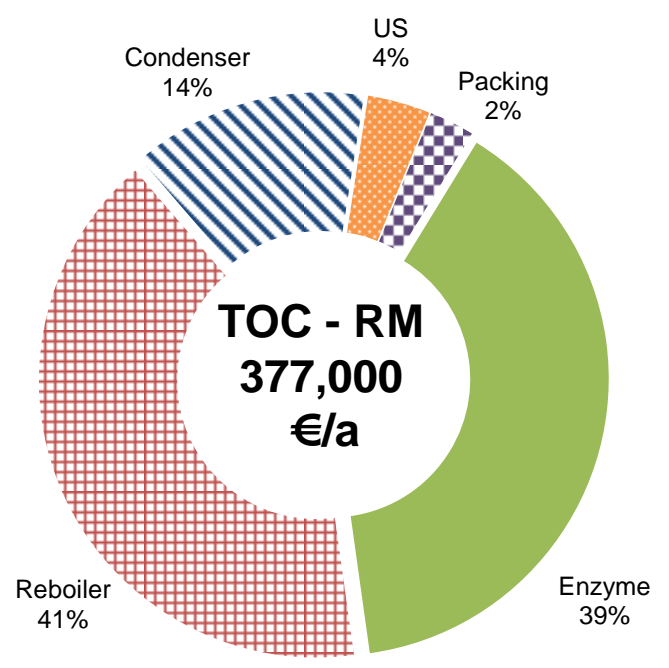

$\mathrm{RM}=17,62$ Mio. $€ / \mathrm{yr}$
Figure 7. Total investment cost (TIC) and total operating cost (TOC) without raw material costs (RM) of the optimized US-ERD process.

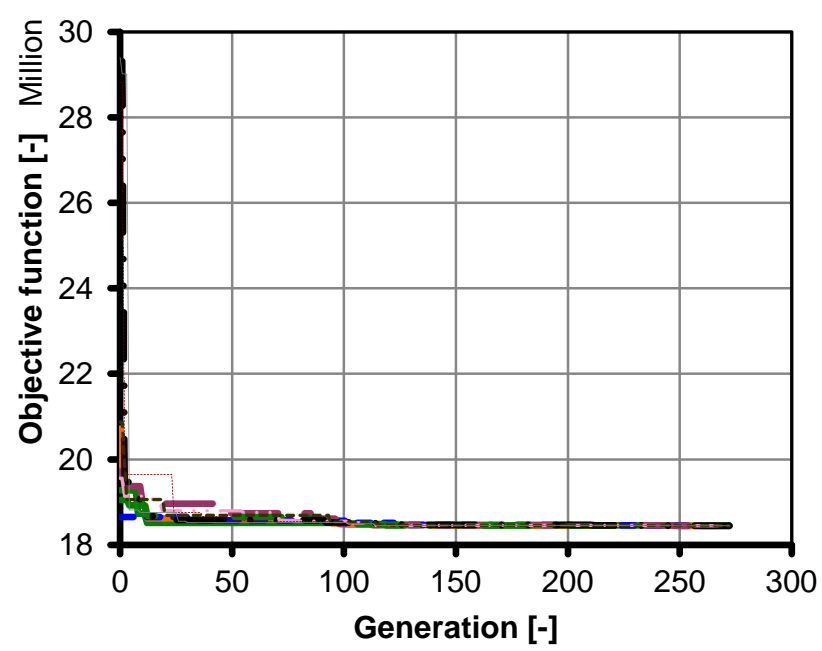

run of US-ERD process. 


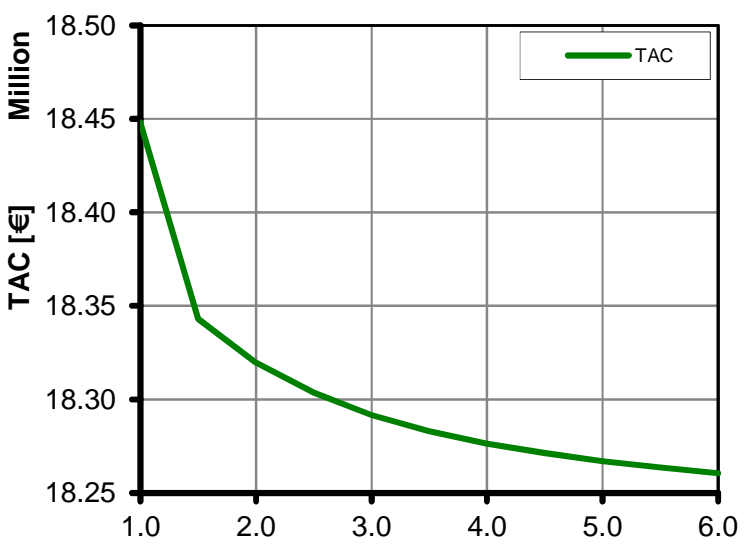

a)

Reaction factor [-]

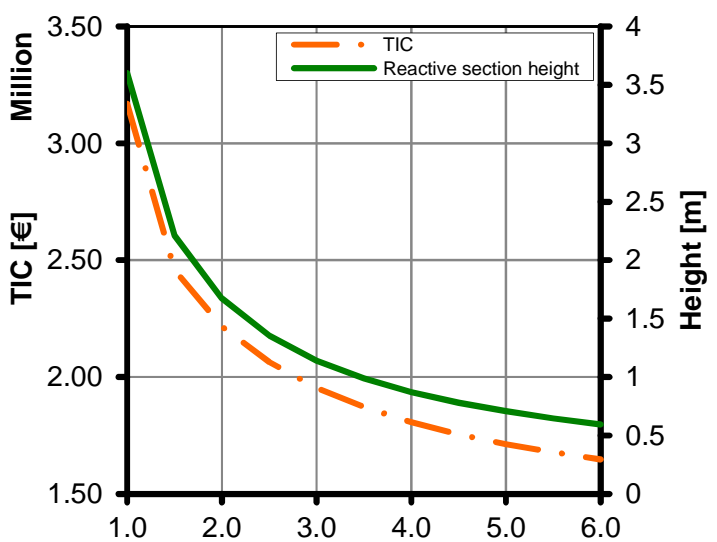

b)

Figure 9. a) Sensitivity analysis for the total annualized costs (TIC) as function of changes in the reaction rate, expressed by a reaction enhancement factor. b) Sensitivity analysis for the total investment costs (TIC) as function of changes in the reaction rate, expressed by a reaction enhancement factor.

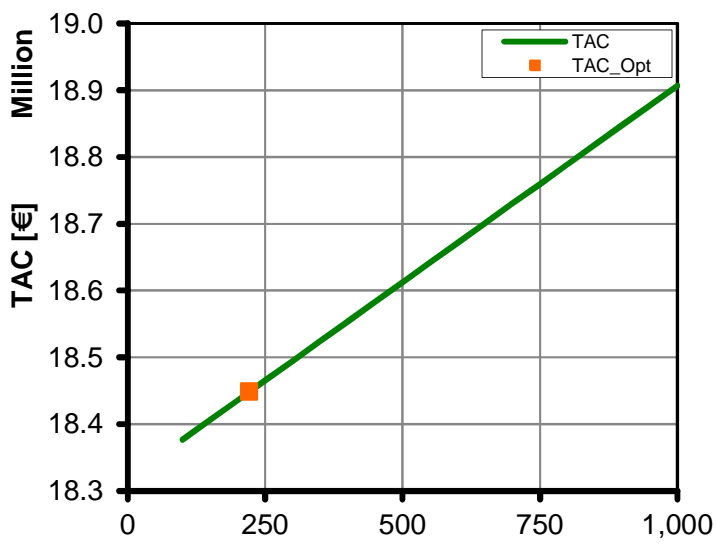

a) TIC_US [€] Thousand

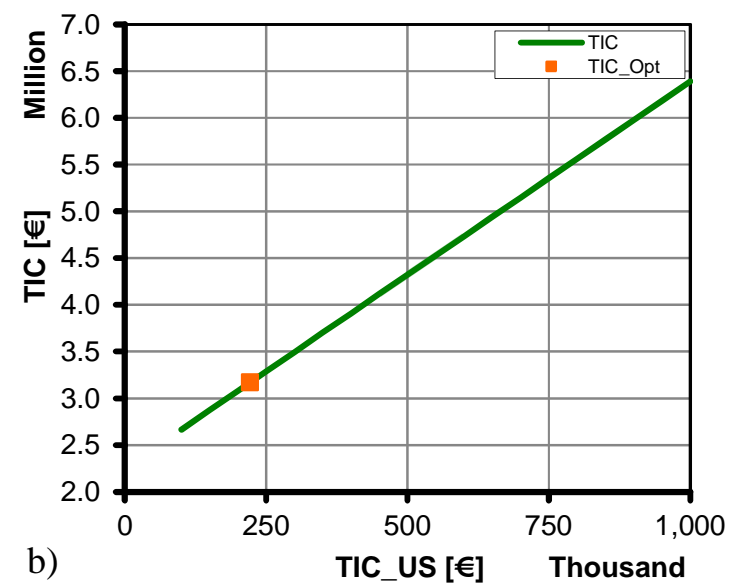

12 Figure 10: a) Sensitivity analysis for the total annualized costs (TAC) as function of changes 13 in the investment costs for bare US equipment. b) Sensitivity analysis for the total investment costs (TIC) as function of changes in the investment costs for bare US equipment. The costs 